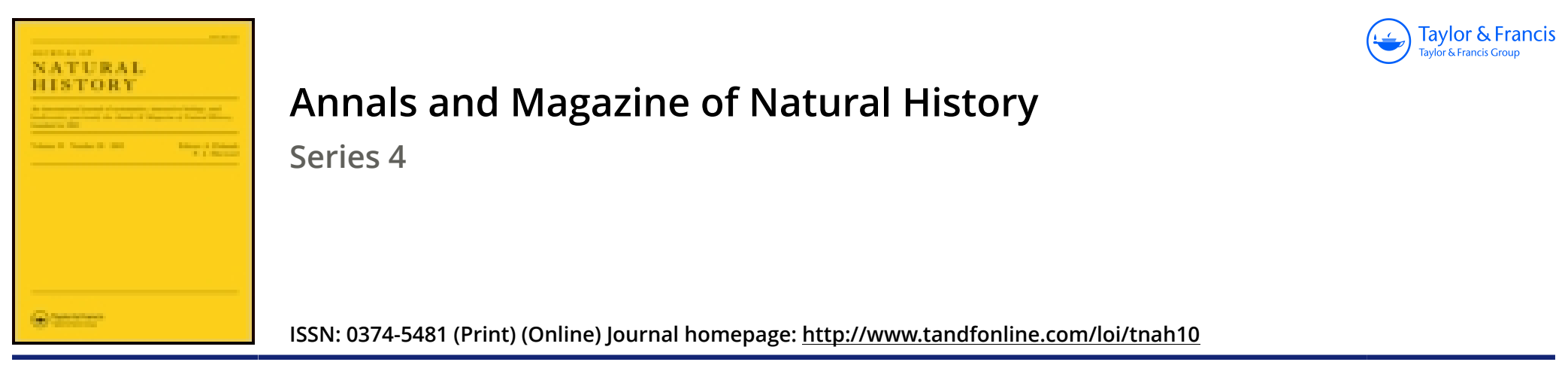

\title{
III.-On a new Parascyllium from Hobson's bay
}

\section{Frederick M'Coy}

To cite this article: Frederick M'Coy (1874) III.-On a new Parascyllium from Hobson's bay , Annals and Magazine of Natural History, 13:73, 15-15, DOI: $10.1080 / 00222937408562423$

To link to this article: http://dx.doi.org/10.1080/00222937408562423

$$
\text { 曲 Published online: } 22 \text { Oct } 2009 .
$$

Submit your article to this journal ๔

Џll Article views: 3

Q View related articles $\asymp$ 
IIT.-On a New Paraseyllium from Hobson's Bay. By Fredenrck M'Cor, Professor of Natural Science in the Melbourne University, and Director of the Melbourne National Museum.

[Plate II.]

To the Editors of the Annals and Magazine of Natural History.

Gentuemen,

As only one species of Parascyllium is noted in Dr. Günther's Catalogue, I beg to give you a brief description of a different one, not very uncommon near Melbourne.

\section{Parascyllium nuchalis, $\mathrm{M}^{\prime} \mathrm{Coy}$.}

Spec. char. Body and fins clouded with two shades of chocolate-brown, with a broad blackish-brown nuchal collar extending from the base of the pectorals to halfway between the eye and the first gill-opening, and two or three very conspicuous large spots of the same dark colour on each of the fins; the whole of the sides and back covered with white spots, smaller and more crowded on the dark nuchal collar; underside of throat and abdomen pale whitish brown. Mouth nearer the extremity of the snout than to the eye.

Length 2 feet 9 inches; snout to anterior edge of orbit 1 inch, to base of pectoral $3 \frac{3}{4}$ inches, to origin of ventrals $11 \frac{1}{2}$

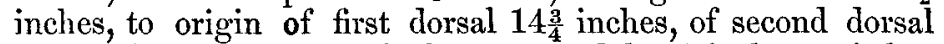
$20 \frac{1}{2}$ inches, of anal 20 inches, to caudal 25 inches; girth 7 inches.

This beautiful species is adult at the above size, and is easily recognized by its brown-clouded body, dark, wide half collar, and conspicuous round white spots.

IV.-On the Genera Tremarctos, Gervais (Nearctos, Gray), and Alurina, Gervais (Ailurogale, Fitz.). By ThEodone GILL, M.D., Ph.D.

Is the 'Annals and Magazine of Natural History' for August 1873 (vol. xii. p. 183) Dr. Gray has differentiated from the genus to which he had formerly referred it (Helarctos) the Ursus ornatus of Frederick Cuvier, giving to that species the new generic name "Nearctos." A distinct subgenus had, however, been long previously proposed for that species by Gervais ' 'Hist. Nat. des Mammifères'' tome ii. 1855, p. 20), and named by him Tremarctos. The name evidently refers to one of the characters mentioned as peculiar-the supra- 
Ann \& Mag.Nat.Hist. S.4.Vol.13.Pl.II.
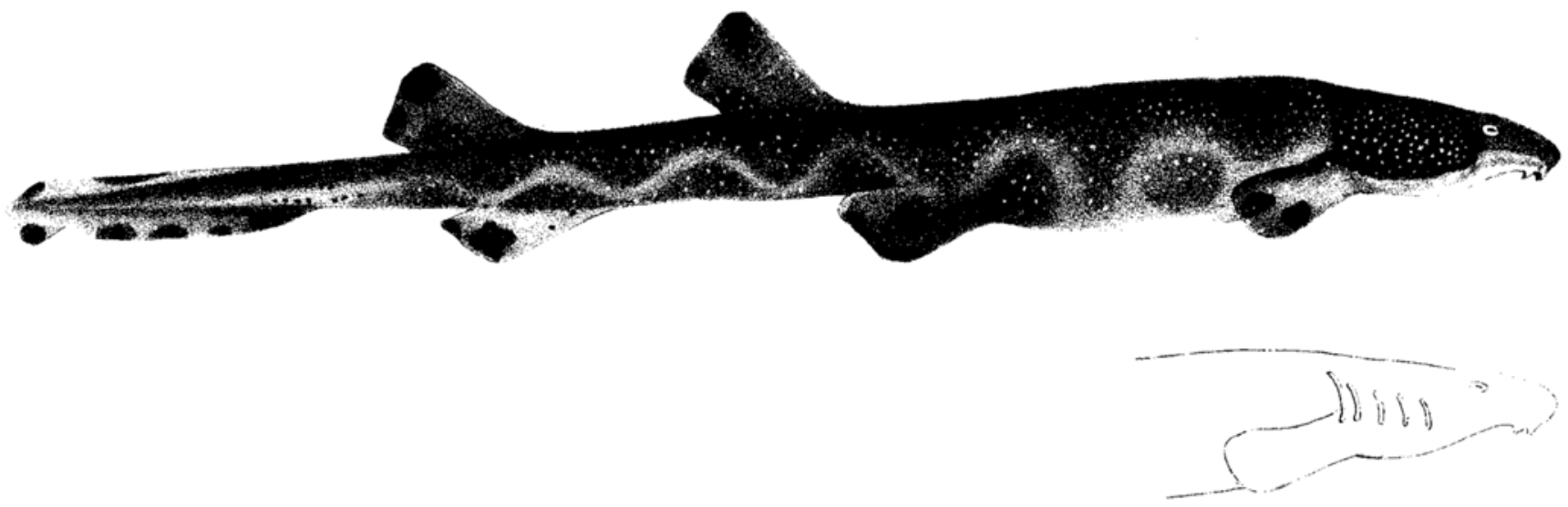

R. Minwern ith

Mintern Bros imt: 